\title{
Chlamydia trachomatis respiratory infection in Dutch infants
}

\author{
G I J G Rours, ${ }^{1,5}$ M R Hammerschlag, ${ }^{2}$ G J J Van Doornum, ${ }^{3}$ W C J Hop, ${ }^{4}$ R de Groot, ${ }^{1}$ \\ H F M Willemse, ${ }^{5} \mathrm{H}$ A Verbrugh, ${ }^{5} \mathrm{R}$ P Verkooyen ${ }^{5}$
}

${ }^{1}$ Division of Paediatric Infectious

Diseases \& Immunology, Department of Paediatrics, Erasmus MC, Rotterdam, The Netherlands; ${ }^{2}$ Division of Pediatric Infectious Diseases, Department of Pediatrics, State University of New York Downstate Medical Center, Brooklyn, New York, USA; ${ }^{3}$ Department of Virology, Erasmus MC, Rotterdam, The Netherlands; ${ }^{4}$ Department of Epidemiology \& Biostatistics, Erasmus MC, Rotterdam, The Netherlands; ${ }^{5}$ Department of Medical Microbiology and Infectious Diseases, Erasmus MC, Rotterdam,

The Netherlands

Correspondence to: Dr G I J G Rours, Department of Paediatrics, Erasmus MC, Dr Molewaterplein 60, $3015 \mathrm{GJ}$ Rotterdam, The Netherlands: g.rours@erasmusmc.nl

Accepted 23 March 2009 Published Online First 23 April 2009

\section{ABSTRACT}

Chlamydia trachomatis is the most common bacterial pathogen causing sexually transmitted infections in Dutch adults. As prenatal screening for $C$ trachomatis and treatment of pregnant women is not routine practice in The Netherlands, perinatal transmission of $C$ trachomatis may therefore occur. The presence of $C$ trachomatis in infants less than 6 months of age who presented with respiratory complaints to the Erasmus MC-Sophia hospital was evaluated. Respiratory specimens, primarily nasopharyngeal swabs, were tested for $C$ trachomatis, respiratory viruses and Mycoplasma pneumoniae using PCR, viral isolation in cell cultures and direct immunofluorescence. $C$ trachomatis respiratory tract infection was confirmed to be relatively common with detection in 10 of 148 (7\%) infants tested. C trachomatis had not been tested for by the attending physicians, but was the second most frequently detected respiratory pathogen after human Respiratory Syncitial Virus, which was found in $41(28 \%)$ infants.

Although Chlamydia trachomatis is currently the most prevalent sexually transmitted bacterial infection in The Netherlands, pregnant women are not screened for $C$ trachomatis infection in The Netherlands, and it is not a notifiable disease. The prevalence of $C$ trachomatis infection among pregnant women in Rotterdam, however, is approximately $6 \% .{ }^{1}$ Recently, we reported that $C$ trachomatis was a major cause of neonatal conjunctivitis in infants less than 3 months of age in our population in Rotterdam. ${ }^{2}$

In the present study, we evaluated the presence of $C$ trachomatis respiratory-tract infection in infants presenting with respiratory complaints in the same region in Rotterdam, The Netherlands.

\section{METHODS}

The study was conducted at the Erasmus MCSophia Hospital, Rotterdam, The Netherlands. C trachomatis screening is not standard practice in pregnant women in the study area; testing is done on clinical suspicion only. Respiratory specimens (nasopharyngeal aspirates or broncho-alveolar lavages) were collected from infants less than 6 months of age who presented with symptoms and signs compatible with respiratory-tract infection to the hospital between January 2002 and January 2003. All specimens were prospectively tested for viral pathogens and Mycoplasma pneumoniae, and retrospectively tested for $C$ trachomatis. Clinical data, eosinophil count and chest $x$ ray results were collected through a systematic review of medical records.
Initially, the samples were sent to the virology laboratory specifically requesting a test for respiratory viruses. Routine virological testing for respiratory pathogens was performed using direct immunofluorescence on cells in respiratory specimens, virus isolation in cell cultures and immunofluorescence, and included human Respiratory Syncitial Virus (hRSV), influenza A, B and C viruses, human $\mathrm{p}$-influenza virus types $1-4$, adenovirus and rhinovirus. Following a diagnosis of picornavirus, nucleic acid amplification techniques were performed with specific primers. Thereafter, samples were stored at $-70^{\circ} \mathrm{C}$ until processing for $C$ trachomatis detection in the present study. Detection of human Metapneumovirus (hMPV), $M$ pneumoniae and $C$ trachomatis was done by PCR.

Data were analysed using SPSS 10.0.0 (SPSS, Chicago). A $p$ value of $<0.05$ was considered significant.

\section{RESULTS}

A total of 157 infants were eligible for the study. From nine infants, the specimens were consumed while testing for viral pathogens during admission. From 148 (94\%) infants, 187 respiratory specimens (184 nasopharyngeal aspirates and three bronchoalveolar lavage fluids) were available for $C$ trachomatis testing. The mean age of the infants was 67 (SD 49) days (range 1 to 172 days); 68 of 148 (46\%) were female and 80 of 148 (54\%) male.

Potential respiratory pathogens were identified in 67 of 148 (45\%) infants. C trachomatis was detected in 10 [7\%] infants. Among the viral pathogens, hRSV was detected in 41 [28\%] infants, followed by rhinovirus (six of $148(4 \%)$ ), influenza A virus (three of $147(2 \%)$ ), adenovirus (two of 147 (1\%)), p-influenza 3 virus (two of $147(1 \%))$ and $p$ influenza 1 virus (1 of $147(1 \%))$. Influenza B and C virus, p-influenza 2 and 4 virus, hMPV and $M$ pneumoniae were not detected. One (10\%) C trachomatis positive infant was also infected with hRSV.

Comparison of $C$ trachomatis and viral pathogens by age group (less than 3 months vs 3-6 months) showed that both $C$ trachomatis and hRSV infections were more often observed in the younger group (fig 1). Eight of $10(80 \%) C$ trachomatis infections occurred before 3 months of age. hRSV was the most common pathogen detected in both age groups.

The underlying pathology and clinical characteristics of the $10 \mathrm{C}$ trachomatis positive infants and their mothers are shown in table 1 . Most infants had significant underlying disease except for patients 4 and 5 . Five infants had a history of 
Table 1 Characteristics of Chlamydia trachomatis positive infants and their mothers

\begin{tabular}{|c|c|c|c|c|c|c|c|c|c|c|}
\hline Underlying pathology & $\begin{array}{l}\text { Meconium } \\
\text { stained liquor, } \\
\text { pulmonary } \\
\text { haemorrhage } \\
\text { eci }\end{array}$ & $\begin{array}{l}\text { Hypoplastic } \\
\text { left heart } \\
\text { syndrome }\end{array}$ & $\begin{array}{l}\text { 3 } \\
\text { IUGR, } \\
\text { dysmorphism, } \\
\text { microcephaly, } \\
\text { unilateral } \\
\text { choanal atresia } \\
\text { stenosis }\end{array}$ & 4 & - & $\begin{array}{l}\text { Antenatal } \\
\text { asphyxia, } \\
\text { generalised } \\
\text { hypotonia, } \\
\text { epilepsy }\end{array}$ & $\begin{array}{l}\text { Hypoplastic } \\
\text { left heart } \\
\text { syndrome }\end{array}$ & $\begin{array}{l}\text { Acute } \\
\text { myeloid } \\
\text { leukemia }\end{array}$ & $\begin{array}{l}9 \\
\text { Very long-chain } \\
\text { acetyl } \\
\text { coenzyme A } \\
\text { dehydrogenase } \\
\text { deficiency, } \\
\text { hypertrophic } \\
\text { cardiomyopathy }\end{array}$ & $\begin{array}{l}\text { Chronic } \\
\text { eczema, } \\
\text { feeding } \\
\text { intolerance }\end{array}$ \\
\hline \multicolumn{11}{|l|}{ Characteristics } \\
\hline Gravidity & 1 & 1 & 2 & 1 & 4 & 2 & 1 & 1 & 5 & 1 \\
\hline Term delivery & + & + & + & + & + & + & + & + & + & + \\
\hline Vaginal delivery & + & + & + & + & + & $\begin{array}{l}\text { Caesarean } \\
\text { section }\end{array}$ & + & + & + & + \\
\hline \multicolumn{11}{|l|}{ Infant } \\
\hline $\begin{array}{l}\text { Appropriate for } \\
\text { gestational age }\end{array}$ & + & + & $\begin{array}{l}\text { Small for } \\
\text { gestational age }\end{array}$ & + & + & + & + & + & + & + \\
\hline Fever & - & - & + & - & - & - & - & + & + & - \\
\hline Cough & - & + & - & - & + & - & + & - & - & - \\
\hline Apnoea & - & - & - & - & + & - & - & - & - & - \\
\hline Cyanosis & + & + & - & - & + & + & + & - & - & - \\
\hline Retractions & - & - & + & - & + & + & - & - & - & + \\
\hline Wheezing & - & + & - & - & + & - & - & - & - & + \\
\hline Crepitations & + & - & - & - & - & - & - & - & - & - \\
\hline Dyspnoea & + & + & + & - & + & + & + & + & - & + \\
\hline Tachypnoea & + & + & - & + & - & + & + & + & - & + \\
\hline $\begin{array}{l}\text { Oxygen } \\
\text { requirement }\end{array}$ & + & + & + & - & + & + & + & - & - & - \\
\hline $\begin{array}{l}\text { Leucocytes } \\
\left(\times 10^{9} / 1\right)\end{array}$ & 12.7 & 9.0 & 9.0 & 14.1 & 4.6 & 10.8 & 9.4 & 1.3 & 23.0 & 26.0 \\
\hline Eosinophils $\left(\mathrm{mm}^{3}\right)$ & 889 & 720 & 90 & 1128 & ND & ND & 752 & 0 & ND & 780 \\
\hline \multicolumn{11}{|c|}{ Viral pathogens } \\
\hline $\begin{array}{l}\text { Human } \\
\text { Respiratory } \\
\text { Syncitial Virus }\end{array}$ & - & - & - & - & + & - & - & - & - & - \\
\hline
\end{tabular}

IUGR, intra-uterine growth retardation; ND, not done.

conjunctivitis: patient 1 had Klebsiella pneumoniae cultured from a conjunctival specimen 4 days after birth, and patient 3 had Haemophilus influenzae at 22 days of age; eye cultures from the other infants showed no growth. None of the eye samples were tested for $C$ trachomatis. Seven infants had signs compatible with upper-respiratory-tract infection, and most infants had signs compatible with lower-respiratory-tract infection. However, only one patient (\#10) had a characteristic chest $x$ ray with hyperinflation and interstitial infiltrates compatible with chlamydial pneumonia. Bacterial cultures of the nasopharynx, sputum and/or blood were negative for all infants except patients 3 and 5, who had $H$ influenzae and Moraxella catarrhalis with Klebsiella oxytoca in the sputum.

Two $C$ trachomatis positive nasopharyngeal specimens were obtained from patient 8: at the age of 65 days and 174 days. On both occasions, she had rhinorrhea and congestion.

\section{DISCUSSION}

In this study, $C$ trachomatis was detected in $7 \%$ of infants less than 6 months of age presenting to hospital with respiratorytract infection. The role of $C$ trachomatis as a causative pathogen for respiratory disease in young infants is well described in the literature. ${ }^{3}$ All respiratory specimens in our study were sent for viral tests, but none were sent for $C$ trachomatis. This suggests that the attending physicians have a low index of suspicion for $C$ trachomatis infection in these infants.

The main limitations of the study are the retrospective design, lack of controls and the fact that we only included infants who presented to hospital. Therefore, this study cannot be regarded as a population-based study of the frequency of chlamydial infections. Neither can we be sure that $C$ trachomatis is the causative pathogen of the respiratory complaints in these infants instead of being coincidental finding. It does, however, 


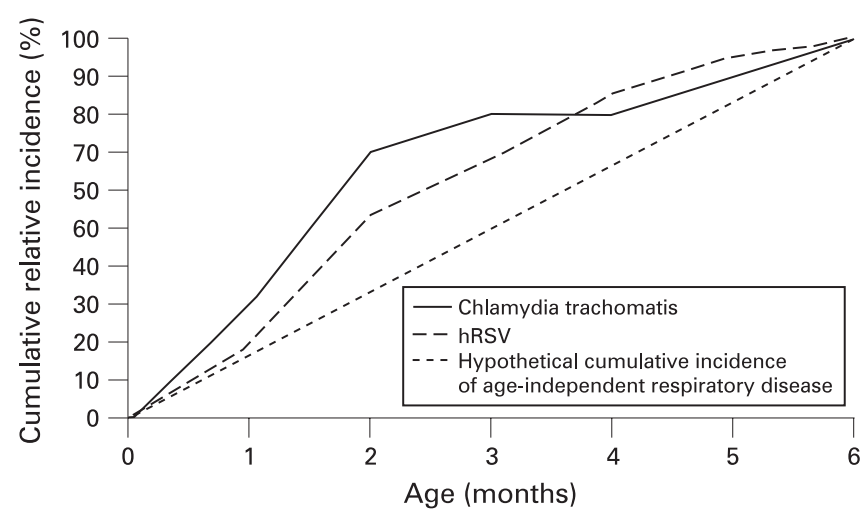

Figure 1 Cumulative relative incidence of Chlamydia trachomatis and human Respiratory Syncitial Virus (hRSV) infection in infants presenting with respiratory tract infection.

demonstrate the relative importance of perinatally acquired $C$ trachomatis infection among infants with respiratory complaints in this population.

The nasopharynx is the most frequent site for perinatally acquired $C$ trachomatis infection, but only about $20 \%$ of infants with nasopharyngeal infection go on to develop pneumonia. Nasopharyngeal infection is usually asymptomatic and selflimiting but may persist for periods of up to 1 year. C trachomatis pneumonia has a characteristic presentation. Infants usually present between 3 and 12 weeks of age with tachypnoea, with a distinctive (staccato paroxysmal) cough and are usually afebrile. Chest auscultation reveals crepitations, with no or minimal wheezing. Chest $x$ rays show hyperexpansion with bilateral, diffuse interstitial and patchy alveolar infiltrates. Peripheral eosinophilia and elevated anti-C trachomatis IgM antibodies may be present. ${ }^{3}{ }^{4}$ In our study, we found 10 infants with $C$ trachomatis nasopharyngeal infection, and only one infant had the characteristic presentation of chlamydial pneumonia with infiltrates present on chest $x$ ray. Interestingly, more than half the infants were dyspnoeic or cyanotic, or required oxygen support. Respiratory failure has been described with chlamydial infection, but is relatively uncommon and mainly described in preterm infants with an early-onset respiratory distress syndrome..$^{5}$ Therefore, the more severe, atypical course of chlamydial infection in our infants may rather be due to underlying pathology, which included significant cardiopulmonary disease, antenatal hypoxia, acute myeloid leukaemia and intrauterine growth retardation with microcephaly and dysmorphic features.

In conclusion, this study demonstrated that perinatal respiratory infection with $C$ trachomatis is common in The Netherlands. We recommend that in countries such as The Netherlands, where screening for $C$ trachomatis is not part of routine antenatal care, testing for $C$ trachomatis should be included in diagnostic and treatment protocols for respiratory disease in infants during the first 6 months of life.

Competing interests: None.

Ethics approval: Ethics approval was provided by Erasmus MC.

\section{REFERENCES}

1. Rours GI, Verkooyen RP, Willemse HF, et al. Use of pooled urine samples and automated DNA isolation to achieve improved sensitivity and cost-effectiveness of large-scale testing for Chlamydia trachomatis in pregnant women. J Clin Microbiol 2005;43:4684-90.

2. Rours GI, Hammerschlag MR, Ott A, et al. Chlamydia trachomatis as a cause of neonatal conjunctivitis in Dutch infants. Pediatrics 2008;121:e321-6.

3. Darville T. Chlamydia trachomatis infections in neonates and young children. Semin Pediatr Infect Dis 2005;16:235-44.

4. Chen CJ, Wu KG, Tang RB, et al. Characteristics of Chlamydia trachomatis infection in hospitalized infants with lower respiratory tract infection. J Microbiol Immunol Infect 2007:40:255-9.

5. Sollecito D, Midulla M, Bavastrelli M, et al. Chlamydia trachomatis in neonatal respiratory distress of very preterm babies: biphasic clinical picture. Acta Paediatr 1992;81:788-91. 


\section{Chlamydia trachomatis respiratory infection} in Dutch infants

G I J G Rours, M R Hammerschlag, G J J Van Doornum, et al.

Arch Dis Child 2009 94: 705-707 originally published online April 23, 2009

doi: $10.1136 /$ adc.2008.152066

Updated information and services can be found at:

http://adc.bmj.com/content/94/9/705.full.html

These include:

References This article cites 5 articles, 2 of which can be accessed free at: http://adc.bmj.com/content/94/9/705.full.html\#ref-list-1

Email alerting Receive free email alerts when new articles cite this article. Sign up in service the box at the top right corner of the online article.

Topic Articles on similar topics can be found in the following collections Collections

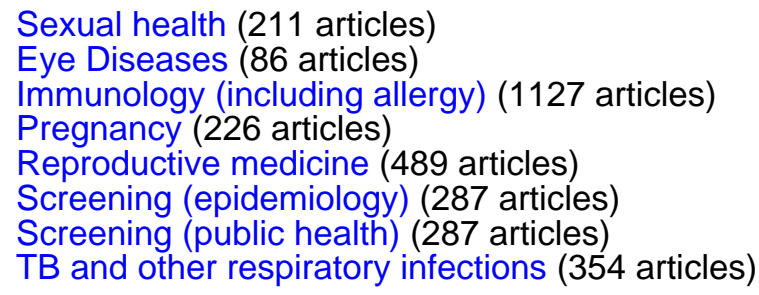

Notes

To request permissions go to:

http://group.bmj.com/group/rights-licensing/permissions

To order reprints go to:

http://journals.bmj.com/cgi/reprintform

To subscribe to BMJ go to:

http://group.bmj.com/subscribe/ 